\title{
Temporal and Spatial Cellular Distribution of Neural Crest Derivatives and Alpha Cells during Islet Development
}

\author{
Kousuke Shimada $^{1}$, Toshiaki Tachibana ${ }^{1}$, Kei Fujimoto ${ }^{2}$, Takashi Sasaki ${ }^{2,3}$ and \\ Masataka Okabe ${ }^{1}$ \\ ${ }^{1}$ Department of Anatomy, The Jikei University School of Medicine, 3-25-8 Nishishinbashi, Minato-ku, Tokyo 105-8461, Japan, \\ ${ }^{2}$ Division of Diabetes and Endocrinology, The Jikei University School of Medicine, 3-25-8 Nishishinbashi, Minato-ku, Tokyo \\ 105-8461, Japan and ${ }^{3}$ Institute of Clinical Medicine and Research, The Jikei University School of Medicine, 163-1 Kashiwashita, \\ Kashiwa, Chiba 277-8567, Japan
}

Received October 31, 2011; accepted December 19, 2011; published online February 15, 2012

\begin{abstract}
Recent studies have revealed that signals from neural crest (NC) derivatives regulate the mass, proliferation, and maturation of beta cells in developing fetal pancreas. However, little is known about the cellular distribution of NC derivatives during pancreatic development or the process whereby the developing islets are enclosed. We studied the temporal and spatial distribution of NC derivatives and endocrine cells at each developmental stage. At embryonic day 10.5 (E10.5) of mouse embryo, NC derivatives that migrated to the prospective pancreatic region were distributed in close proximity to pancreatic epithelial cells. As development advanced, most NC derivatives progressively surrounded endocrine rather than exocrine cells, and were distributed in closer proximity to alpha cells rather than to beta cells. At E20, approximately $70 \%$ of the NC derivatives enclosing endocrine cells were distributed in close proximity to alpha cells. Moreover, the expression of SynCAM, a Ca ${ }^{2+}$-independent homophilic trans-cell adhesion molecule, was confirmed from E16.5 on and was more remarkable at the cell boundaries of alpha cells and NC derivatives. These findings suggest that NC derivatives might be distributed in close proximity to alpha cells as a result of homophilic binding of SynCAM expressed by alpha cells and NC derivatives during islet development.
\end{abstract}

Key words: neural crest, alpha cells, CADM-1 (SynCAM), islet development

\section{Introduction}

Islets of Langerhans are not just endocrine cell clusters composed of alpha and beta cells, but comprise part of an ectodermally-derived nervous system known to innervate the islets during cell development in pancreas. It is therefore presumed that the islets are multicellular complexes comprising endocrine cells that form aggregates with nervous system components [25, 31], and constitute higher-order endocrine units that maintain nutritional and blood glucose homeostasis. Nerve signals are known to improve the

Correspondence to: Masataka Okabe, M.D., Ph.D., Department of Anatomy, The Jikei University School of Medicine, 3-25-8 Nishishinbashi, Minato-ku, Tokyo 105-8461, Japan.

E-mail: maokabe@jikei.ac.jp function of endocrine cells in adults $[6,11,18,26]$, but the detailed functions of the ectodermally-derived cells enclosing pancreatic islets, such as the functions of glial fibrillary acidic protein (GFAP)- and S100-positive peri-islet Schwann cells (PISCs) that surround nerve fibers around the islets $[5,30,34,37]$, remain to be investigated. Although the functional significance of PISCs in endocrine cells in adults remains unclear, it is presumed that nerve-related cells associated with the islets play a key role in protecting the islets for the following reasons: (1) they are the first target of the pathogenesis of type 1 diabetes, (2) their disruption leads to a pathogenic cascade [36, 39], and (3) in a murine model of islet injury type 2 diabetes, the PISCs of mice treated with streptozotocin displayed reactive gliosis [35].

The first morphological indications of pancreatic formation are observed around embryonic day 9.5 (E9.5) of 
the mouse embryo, with the appearance of ventral pancreatic and dorsal buds in a specific portion of the intestinal tract [10]. The pancreatic bud can be detected by the expression of pancreatic and duodenal homeobox 1 (PDX1), which is localized in endocrine cells as development proceeds. These pancreatic buds grow, branch, differentiate, and eventually merge to form the pancreas. As development proceeds, the endocrine cells also differentiate and mature, and gradually form aggregations that eventually merge to form pancreatic islets. The development of the pancreas thus requires not only pancreatic mesoderm and endoderm, but also innervation by ectodermally derived tissues, which occurs at E12.5 [2]. In a recent study, ectoderm-derived neural crest (NC) derivatives were shown to accumulate in close proximity to pancreatic epithelial cells at E10.0 [24]. NC cells are pluripotent and mobile, and they differentiate into many cell types, including peripheral and enteric neurons, glia, melanocytes, and smooth muscle cells [9, 19, 20, 33, 40]. Signals from NC derivatives are also known to be essential for the maturation of beta cells [24]. However, despite the importance of NC derivatives in the development of endocrine cells, little is known about the cellular distribution of both NC derivatives and endocrine cells, or the process whereby $\mathrm{NC}$ derivatives enclose the latter during the development of the pancreas. Here, we report our examination of the temporal and spatial distribution of NC derivatives and endocrine cells during the development of the pancreas and our observations of the behavior of the NC derivatives during the formation of pancreatic islets.

\section{Materials and Methods}

Animals

All experiments were performed in accordance with the guidelines of the local ethics committee of the Jikei University School of Medicine. Transgenic Wnt1-Cre mice expressing Cre recombinase under control of the Wnt1 promoter/enhancer [B6.Cg-Tg (Wnt1-Cre) 11Rth Tg (Wnt1-GAL4) 11Rth/J] were mated with indicator mice (CAG-CATloxP/loxP-EGFP) [4, 16] to obtain Wnt1Cre/Floxed-EGFP mice. Wnt1-Cre/Floxed-EGFP mice express enhanced green fluorescent protein (EGFP) in all $\mathrm{NC}$ cells and their derivatives. When a vaginal plug appeared, the day was designated 0.5 days post-coitum. Wnt1Cre/Floxed-EGFP embryos were selected on the basis of EGFP expression. Adult Wnt1-Cre/Floxed-EGFP mice were selected for PCR-based genotyping with primers for the Cre and CAT genes. The embryos used for the experiments were collected at different developmental stages, which were defined as follows: early stage pancreatic development, E10.5-E12.0; mid-stage pancreatic development, E12.5E15.5; and late stage pancreatic development, E16.5-E20.

\section{Immunohistochemistry}

For histological analyses, samples were fixed in $4 \%$ paraformaldehyde in phosphate-buffered saline (PBS) at $4^{\circ} \mathrm{C}$ overnight, soaked in different concentrations of sucrose/PBS buffer $(10,20$, and $30 \%)$ at $4^{\circ} \mathrm{C}$ for $1 \mathrm{hr}$, embedded in Tissue-Tek OCT compound, and frozen. Frozen sections

Table 1. Primary and secondary antibodies for immunohistchemistry

\begin{tabular}{|c|c|c|c|}
\hline primary and secondary antibody & working dilution & type & source \\
\hline green fluorescent protein (GFP) & $1: 1000$ & chick polyclonal & Aves \\
\hline green fluorescent protein (GFP) & $1: 1000$ & rabbit polyclonal & Abcam \\
\hline Insulin & $1: 500$ & guinea pig polyclonal & Dako \\
\hline Glucagon & $1: 2000$ & mouse monoclonal & Sigma \\
\hline Glucagon & $1: 200$ & rabbit polyclonal & Cell Signaling Technology \\
\hline Glial fibrillary acidic protein (GFAP) & $1: 500$ & rabbit polyclonal & Dako \\
\hline S 100 & $1: 1000$ & rabbit polyclonal & Dako \\
\hline neurofilament $160 \mathrm{kDa}(\mathrm{NF}-\mathrm{M})$ & $1: 1000$ & chick polyclonal & Aves \\
\hline tyrosine hydroxylase $(\mathrm{TH})$ & $1: 1000$ & rabbit polyclonal & Millipore \\
\hline calcitonin gene-related peptide (CGRP) & $1: 2000$ & rabbit polyclonal & Calbiochem \\
\hline choline acetyltransferase (ChAT) & $1: 30$ & rabbit polyclonal & Abcam \\
\hline neuronal protein $\mathrm{HuC} / \mathrm{HuD}$ & $1: 50$ & mouse monoclonal & Molecular Probes \\
\hline Pancreatic and duodenal homeobox 1 (PDX1) & $1: 400$ & rabbit polyclonal & Trans Genic \\
\hline SynCAM & $1: 500$ & chick polyclonal & MBL \\
\hline Alexa Fluor 488 & 1:1000 & $\begin{array}{l}\text { goat anti-rabbit, goat anti-chick, goat } \\
\text { anti-guinea pig }\end{array}$ & Molecular Probes \\
\hline Alexa Fluor 555 & $1: 1000$ & $\begin{array}{l}\text { goat anti-rabbit, streptoavidin } \\
\text { conjugated }\end{array}$ & Molecular Probes \\
\hline Alexa Fluor 633 & $1: 1000$ & $\begin{array}{l}\text { goat anti-rabbit, goat anti-guinea pig, } \\
\text { streptoavidin conjugated }\end{array}$ & Molecular Probes \\
\hline DyLight549 & $1: 500$ & goat anti-chick & Jackson ImmunoResearch \\
\hline
\end{tabular}

Abcam: Cambridge, UK; Aves: Oregon, USA; Calbiochem: Darmstadt, Germany; Cell Signaling Technology: Danvers, USA; Dako: Copenhaven, Denmark; Jackson ImmunoResearch: West Grove, PA, USA MBL: Nagoya, Japan; Millipore: Billerica, USA; Molecular Probes: Merelbeke, Belgium; Sigma-Aldrich; St. Louis, MO, USA; Trans genic: Kumamoto, Japan. 
$(10-\mu \mathrm{m}$ thick) were incubated with blocking solution $(10 \%$ normal goat serum plus $0.1 \%$ Tween-20 in PBS) at room temperature for $10 \mathrm{~min}$. Primary antibodies were diluted in the antibody dilution buffer ( $1 \%$ normal goat serum plus $0.1 \%$ Triton-X100 in PBS), and incubated at $4{ }^{\circ} \mathrm{C}$ overnight. Primary and secondary antibodies used in this study are described in Table 1. Biotinylated anti-mouse IgG reagent (1:500, Vector: Burlingame, CA, USA) was used for mouse on mouse staining, and the results were visualized using streptavidin conjugated with Alexa555 or Alexa633 (1:500). Nuclei were stained with 4,6-diamino-2-phenylindole
(DAPI) solution (1:1000, Dojindo: Kumamoto, Japan). The immunostained samples were observed with a confocal laser scanning microscope (LSM510 META, Carl Zeiss) and a fluorescence microscope (Axio Imager, Axiocam, Carl Zeiss).

\section{Results}

\section{Islets enclosed by NC derivatives}

In adult mice, the islets were surrounded by nerve fibers, GFAP and S100-positive PISCs (Fig. 1A, B). These
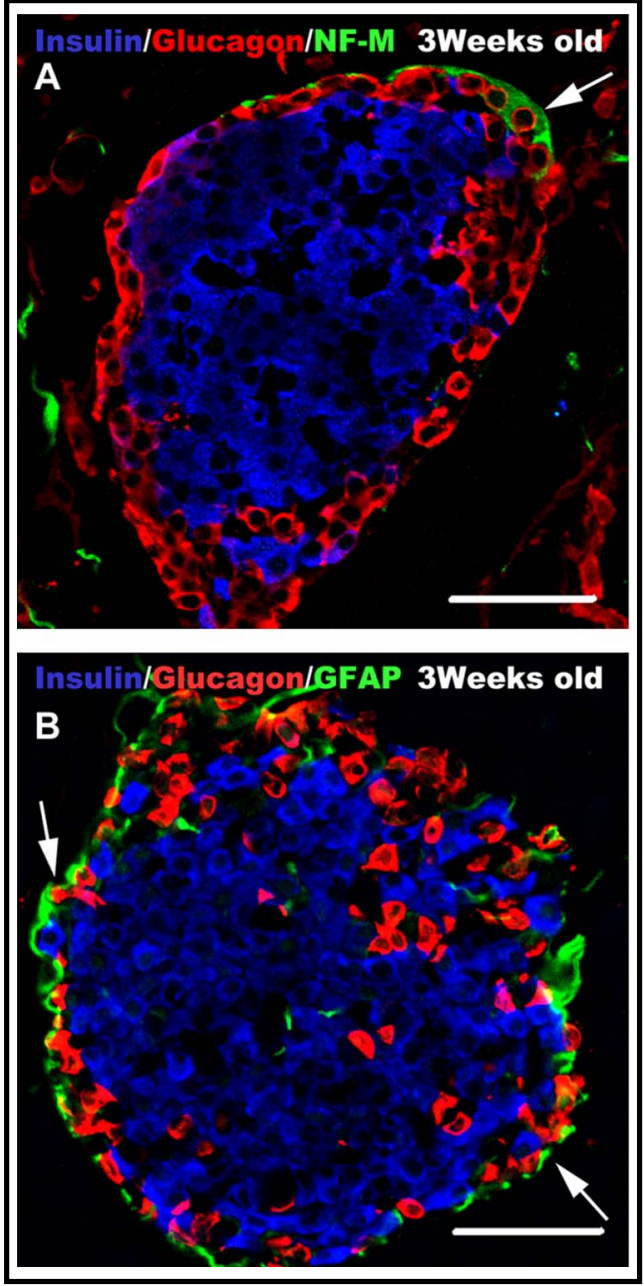
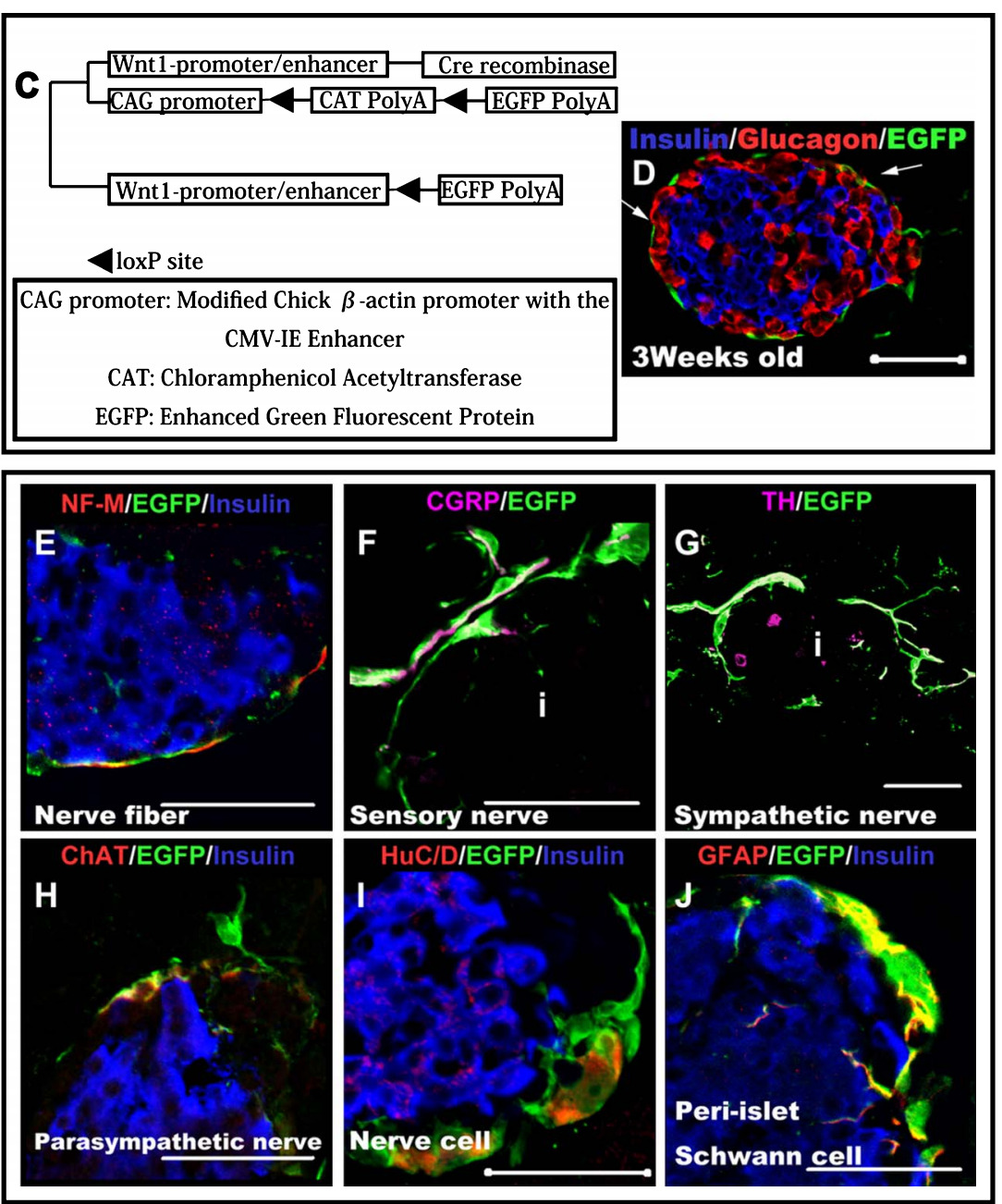

Fig. 1. Neural crest (NC) derivatives surrounding islets differentiated into neural-related cells and tended to be distributed in closer proximity to alpha cells. (A and B) Three-week-old mouse cells stained with neurofilament (NF-M) (green) (A), glial fibrillary acidic protein (GFAP) (green) (B), insulin (blue) (A and B), and glucagon (red) (A and B) antibodies, showing immunoreactivity in regions surrounding the islets. Most of the nerve-related cells tended to be located in closer proximity to alpha cells than to beta cells (arrows). (C) Constitutive expression of enhanced green fluorescent protein (EGFP) in NC cells and their derivatives in double transgenic Wnt1-Cre/Floxed-EGFP mice. (D) Pancreatic region of a 3-week-old Wnt1-Cre/Floxed-EGFP mouse; the cells were stained with insulin (blue), glucagon (red), and GFP (green) antibodies. EGFP immunoreactivity is observed around the islets. Most NC derivatives tended to be located in closer proximity to alpha cells than to beta cells (arrows). (E-J) To determine the cell types of NC derivatives differentiated into around islets, immunostaining experiments were performed with various nerve-related and EGFP antibodies. Neural fibers (sympathetic nerves $(\mathbf{G})$, parasympathetic nerves $(\mathbf{H})$, and sensory nerves $(\mathbf{F})$ ) surrounding the islets were found to be derived from NC cells. Moreover, pancreatic ganglion cells (I) that made contact with islets were also found to be derived from NCs. peri-islet Schwann cells (PISCs) $(\mathbf{J})$ surrounding the islets were also derived from NC cells. Bar=50 $\mu \mathrm{m}$ for all Figures. $i=$ Islet. 
nerve-related cells surrounding the islets were assumed to originate from the NC cells. We confirmed the types of cells the $\mathrm{NC}$ derivatives differentiated into in the pancreas using a transgenic mouse line that expresses EGFP in all NC cells and their derivatives (Fig. 1C). NC derivatives were widely distributed throughout the pancreas and were located particularly close to blood vessels and the pancreatic islets. Most of the NC derivatives enclosed the islets (Fig. 1D). $\mathrm{NC}$ derivatives surrounding the islets primarily differentiated into the nervous system (Figs. 1E-J). Moreover, most NC derivatives were distributed in close proximity to alpha cells located at the margins of the islets (Fig. 1A, B, and D; arrows). Therefore, our data suggest that cell-cell interactions may occur between the NC derivatives and alpha cells. To investigate their physical relationship, the cellular distribution of both $\mathrm{NC}$ derivatives and endocrine progenitor cells during pancreatic development was examined further.

\section{Relationship between endocrine progenitor cells and NC derivatives during pancreatic development}

The localization of $\mathrm{NC}$ derivatives that migrated to the pancreas was examined using Wnt1-Cre/Floxed-EGFP mice at each developmental stage. The prospective area of the pancreas was identified by the pancreatic epithelial marker

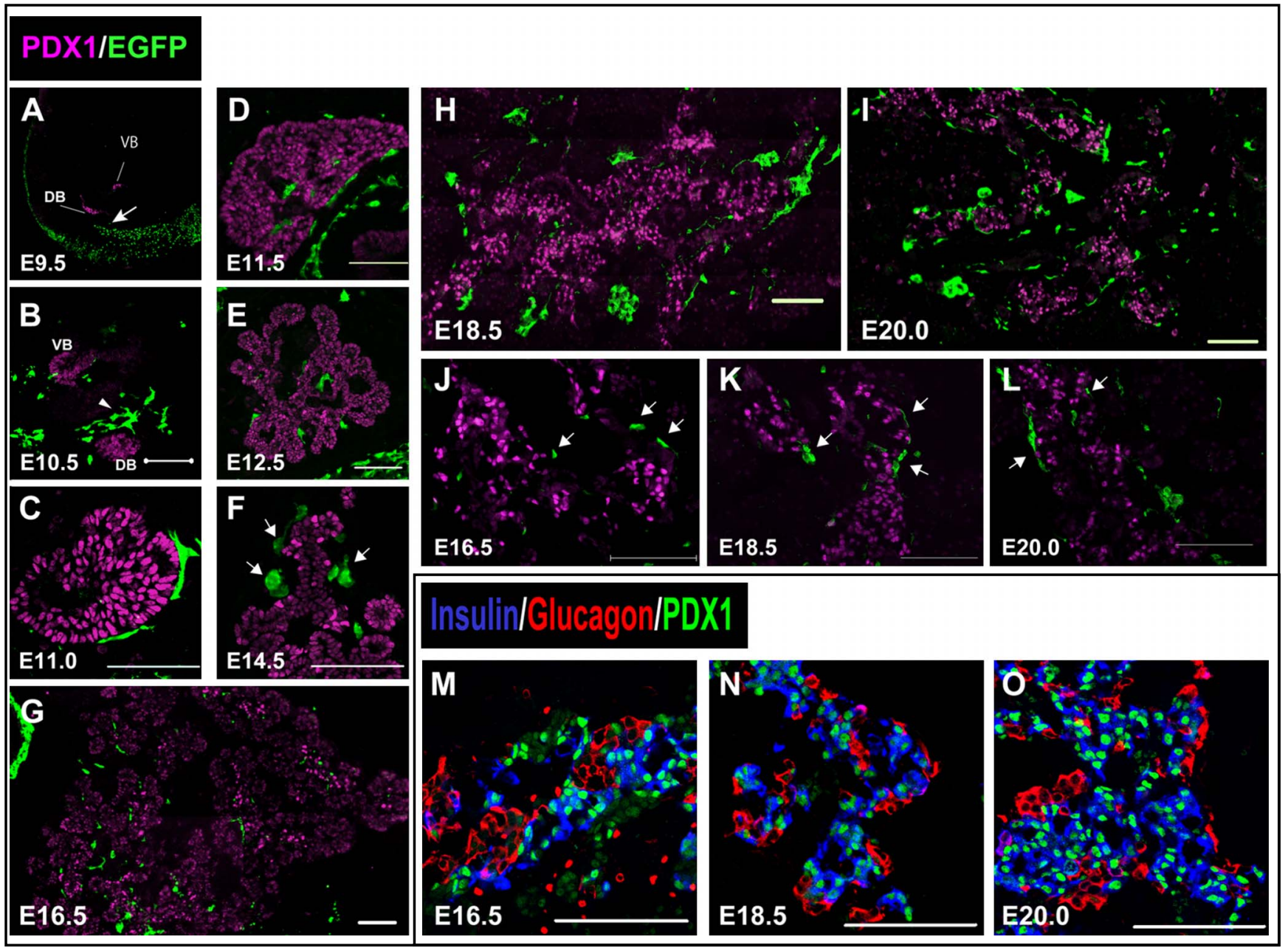

Fig. 2. Distribution of NC derivatives during pancreatic development. (A-L) Immunohistochemical staining of pancreatic regions of Wnt1-Cre/ Floxed-EGFP mouse embryos at each embryonic stage. Staining was performed with pancreatic and duodenal homeobox 1 (PDX1) antibody (magenta) and GFP antibody (green). (A) At embryonic day 9.5 (E9.5), Wnt1-Cre/Floxed-EGFP embryos did not have any NC derivatives in close proximity to the ventral and dorsal pancreatic buds (arrow). (B) At E10.5, NC derivatives were observed in a close proximity to both pancreatic buds. They were closer to the dorsal pancreatic bud than to the ventral pancreatic bud (arrowheads). (C and D) From E11.0, NC derivatives surrounded PDX1-positive cells. (E) At E12.5, as branching of buds progressed, NC derivatives were distributed along the pancreatic epithelial cells. (F) At E14.5, several NC derivatives tended to be located close to cells with high PDX1 expression (arrows). (J-L) Higher magnification image of the region in $\mathbf{G}-\mathbf{I}$, where NC derivatives were distributed in close proximity to PDX1-positive cells (arrows). (M-O) Immunohistochemical staining of pancreatic regions of mouse embryos is shown; staining was performed with insulin antibody (blue), glucagon antibody (red), and PDX1 antibody (green). During later stages of pancreatic development, PDX1-positive cells were mainly localized in insulin-positive rather than glucagon-positive cells. $\mathrm{Bar}=100 \mu \mathrm{m}(\mathbf{B}-\mathbf{O})$. VB=ventral pancreatic bud, $\mathrm{DB}=$ dorsal pancreatic bud. 
PDX1, whereas NC derivatives were identified by EGFP expression. At E9.5, NC derivatives were not observed in proximity to the epithelia of the pancreatic buds (Fig. 2A; arrow). However, at E10.5, NC derivatives were observed in proximity to the epithelia of the ventral and dorsal pancreatic buds (Fig. 2B). Most NC derivatives observed in close proximity to the pancreatic buds were distributed more on the dorsal side than on the ventral side (Fig. 2B; arrowheads). Therefore, $\mathrm{NC}$ derivatives migrated to the prospective region of the pancreas between E9.5-E10.5, and were mostly distributed on the dorsal side of the pancreatic bud. NC derivatives surrounded PDX1-positive cells at E11.0 (Fig. 2C). Many of the NC derivatives in the developing pancreas were scattered along branched pancreatic epithelial cells from E11.5 (Fig. 2D, E). As development advanced, NC derivatives were widely distributed throughout the developing pancreas (Fig. 2F-I). Some of the NC derivatives were distributed in proximity to the cells with a high PDX1 expression from the stage where differentiation into endocrine cells began (Fig. 2F, J-L; arrows). As development advanced, PDX1 expression became localized in endocrine rather than in exocrine cells. From E16.5, PDX1 expression was mainly localized in beta cells, and most alpha cells were PDX1-negative (Fig. 2M-

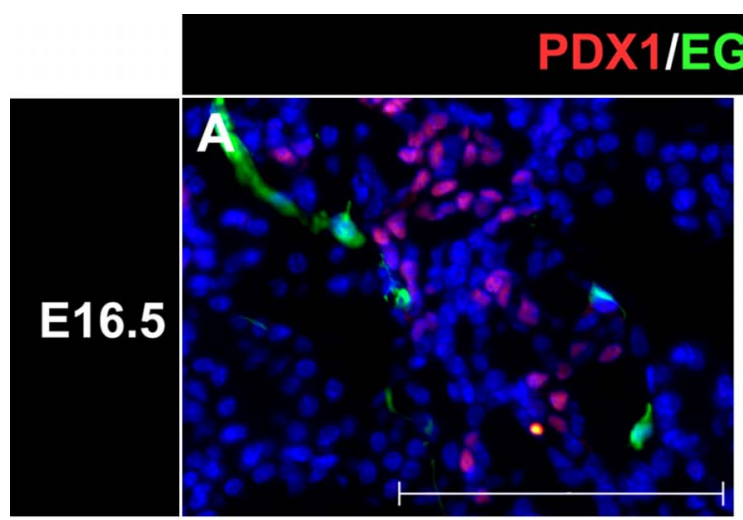

\section{GFP/DAPI}
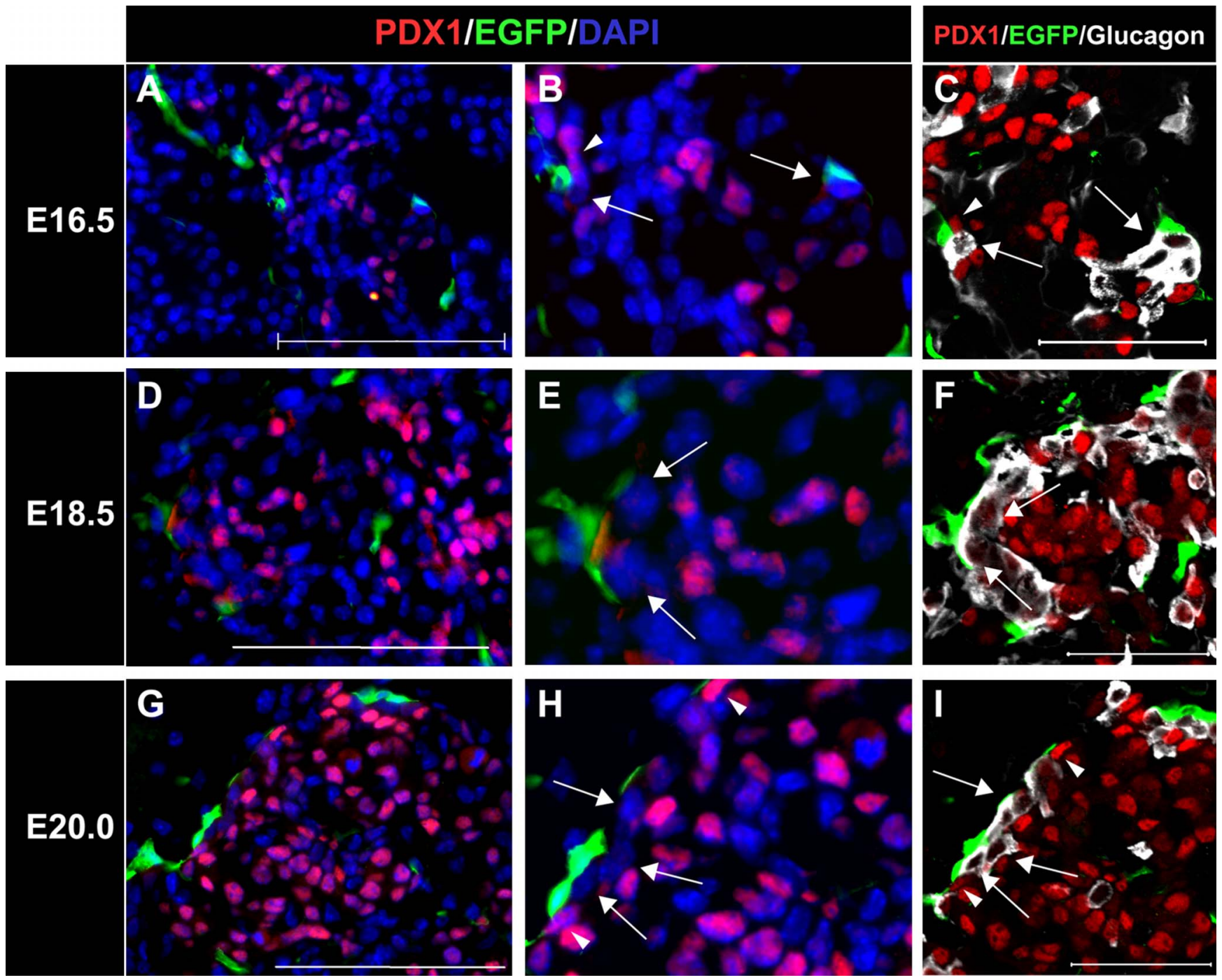

Fig. 3. Glucagon-positive cells tended to be located between PDX1-positive cells and NC derivatives. (A-H) Immunohistochemical staining of pancreatic regions of Wnt1-Cre/Floxed-EGFP mouse embryos during later stages of pancreatic development. Staining was performed with PDX1 antibody (red) and GFP antibody (green), and nuclei were stained with DAPI solution (blue). (C, F, and I) Immunohistochemical staining results with PDX1 antibody (red), GFP antibody (green), and glucagon antibody (white). Figures $\mathbf{B}, \mathbf{E}$, and $\mathbf{H}$ are higher magnification images of $\mathbf{A}, \mathbf{D}$, and $\mathbf{G}$, respectively. NC derivatives were distributed in closer proximity to PDX1-negative cells (arrowheads) than to PDX1-positive cells (arrows). Figures $\mathbf{C}, \mathbf{F}$, and $\mathbf{I}$ represent the same sections as $\mathbf{B}, \mathbf{E}$, and $\mathbf{H}$, respectively, but were stained with glucagon antibody (white). PDX1-negative cells located in close proximity to NC derivative cells were glucagon-positive (arrows). Most NC derivatives tended to be distributed in closer proximity to glucagon-positive cells than to PDX1-positive cells (arrowheads) during later stages of pancreatic development. Bar=50 $\mu \mathrm{m}(\mathbf{A}, \mathbf{D}, \mathbf{G}, \mathbf{C}, \mathbf{F}$, and $\mathbf{I})$. 
O). Therefore, in the late stage of pancreatic development, some of the NC derivatives tended to be distributed in close proximity to beta cells; this is different from the cellular distribution of $\mathrm{NC}$ derivatives and endocrine cells in adults. To investigate this difference, detailed distribution of both $\mathrm{NC}$ derivatives and PDX1-positive cells in the later stages of pancreatic development was examined further.

\section{With development, most $\mathrm{NC}$ derivatives tended not to be in close proximity to PDX1-expressing cells}

Immunostaining experiments to detect endocrine cells and EGFP at the early stage of pancreatic development indicated that a few $\mathrm{NC}$ derivatives tended to be distributed in close proximity to endocrine cells (data not shown). Moreover, from E14.5, some NC derivatives displayed a tendency to approach cells with high PDX1 expression (Fig. 2F, J-H; arrows). As pancreatic development advanced, only beta cells showed high PDX1 expression. Our results, therefore, showed that the majority of cells with high PDX1 expression have a beta-cell lineage. This supports previous findings that signals from NC derivatives regulate the mass, proliferation, and maturation of beta cells. However, we also confirmed that NC derivatives were distributed in closer proximity to alpha cells rather than beta cells during the postnatal stages. During late-stage pancreatic development, although NC derivatives were distributed in close proximity to cells with high PDX1 expression (Fig. 3B and $\mathrm{H}$; arrowheads), several other cell types remained present between the cells with high PDX1 expression and the NC derivatives (Fig. 3B, E, H; arrows). Therefore, we
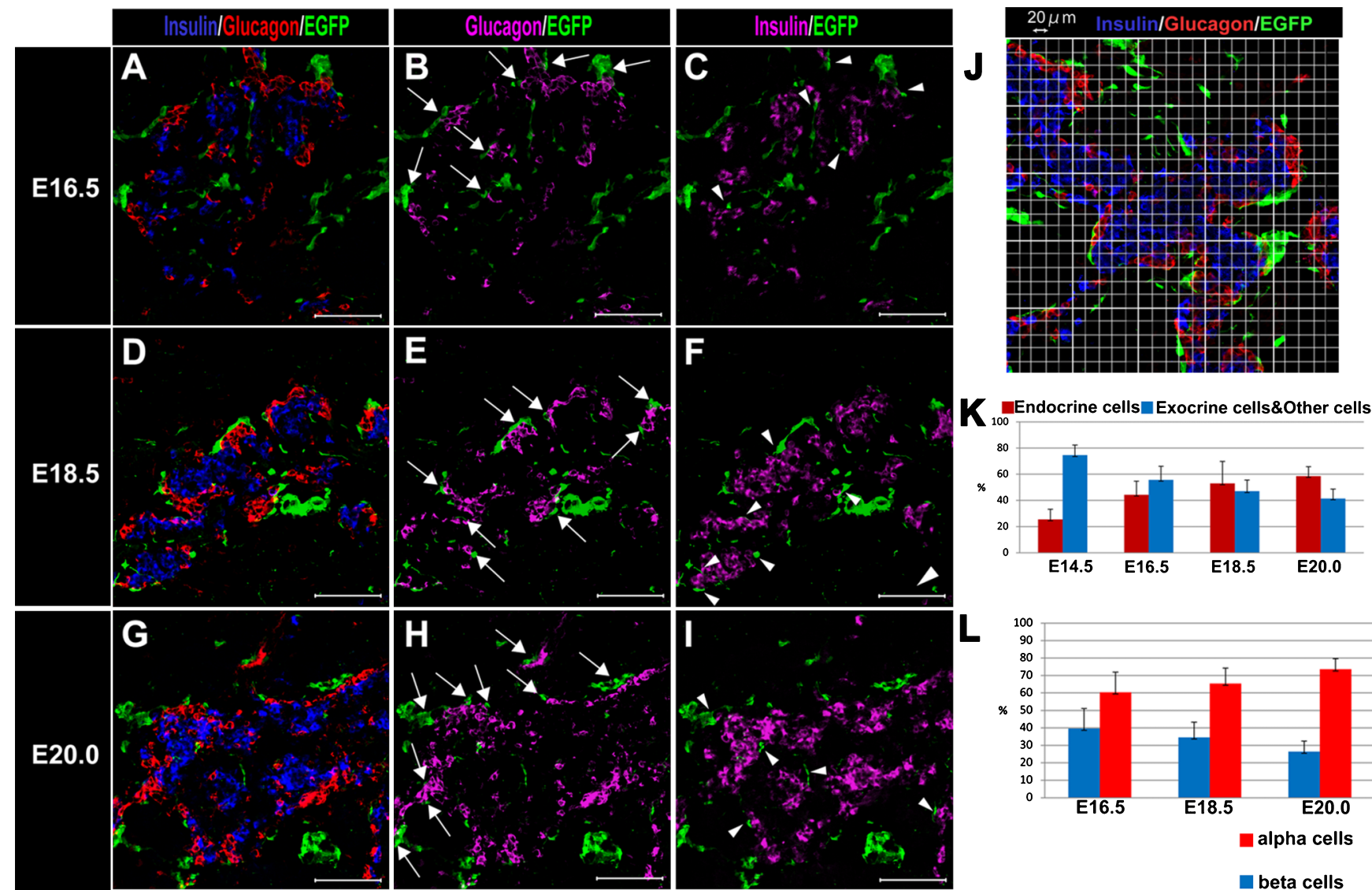

Fig. 4. Distribution of $\mathrm{NC}$ derivatives and endocrine cells during pancreatic development. (A-I) Immunohistochemical staining of pancreatic regions of Wnt1-Cre/Floxed-EGFP mouse embryos during late embryonic stage. Staining was performed with insulin antibody (blue) (A, D, and $\mathbf{G}$ ) (magenta) (C, F, and I), glucagon antibody (RED) (A, D, and $\mathbf{G})$ (magenta) (B, E, and $\mathbf{H}$ ), and GFP antibody (green). (J) Pancreatic region of an E18.5 Wnt1-Cre/Floxed-EGFP mouse embryo stained with insulin antibody (blue), glucagon antibody (red), and GFP antibody (green) and the location of the $20-\mu \mathrm{m}$ grid. From E16.5 on, NC derivatives tended to be distributed in closer proximity to alpha cells (arrows) than to beta cells (arrowheads). To confirm the gradual process by which NC derivatives migrated into closer proximity to endocrine cells, the characteristics of the cells that appeared in the $20-\mu \mathrm{m}$ grid were examined based on the images obtained from the immunostaining experiments in embryos from stages later than E14.5. The results were as follows: (1) as development of the pancreas advanced, the frequency of the appearance of endocrine cells and NC derivatives in the same grid also increased (K); and (2) the frequency of the appearance of glucagon-expressing cells and NC derivatives in the same grid also increased, indicating that alpha cells were in closer proximity to $\mathrm{NC}$ derivatives than to beta cells $(\mathbf{L})$. Therefore, as development advanced, the tendency for NC derivatives to be distributed in closer proximity to alpha cells increased. Bar=100 $\mu \mathrm{m}(\mathbf{A}-\mathbf{I})$. 
suggest that endocrine cells other than beta cells are present between the cells with high PDX1 expression and the NC derivatives. To identify these intervening cells, we examined the cellular distribution of alpha cells, which are PDX1negative during late-stage pancreatic development. Most of the intervening cells were identified as PDX1-negative alpha cells (Fig. 3C, F, I; arrows). These results indicate that during late-stage pancreatic development, alpha cells are found between NC derivatives and cells with high PDX1 expression; hence, most NC derivatives distributed in close proximity to the cells with high PDX1 expression do not come into contact with beta cells directly (Fig. 3C, F, I; arrows and arrowheads).

\section{During late-stage pancreatic development, most NC} derivatives tended to be distributed in close proximity to alpha cells

To investigate the cellular distribution of the NC derivatives and of each endocrine cell type during pancreatic development, we confirmed the cellular distribution of these cells during late-stage pancreatic development. Immunostaining experiments at the early stage of pancreatic development indicated that some $\mathrm{NC}$ derivatives tended to be distributed in close proximity to endocrine cells (data not shown). At E16.5, most NC derivatives tended to be distributed in closer proximity to alpha cells (Fig. 4B; arrows) than to beta cells (Fig. 4C; arrowheads). Moreover,

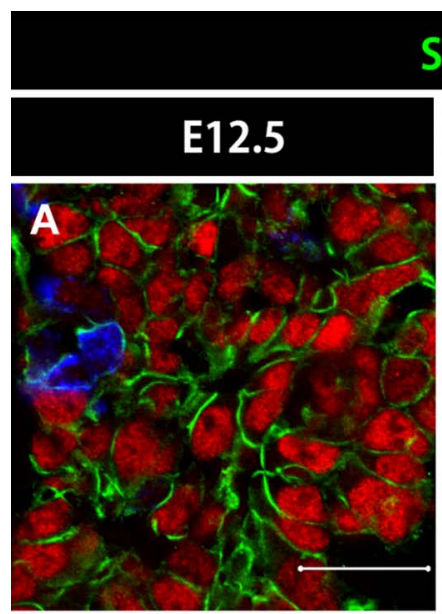

\section{SynCAM/PDX1/}
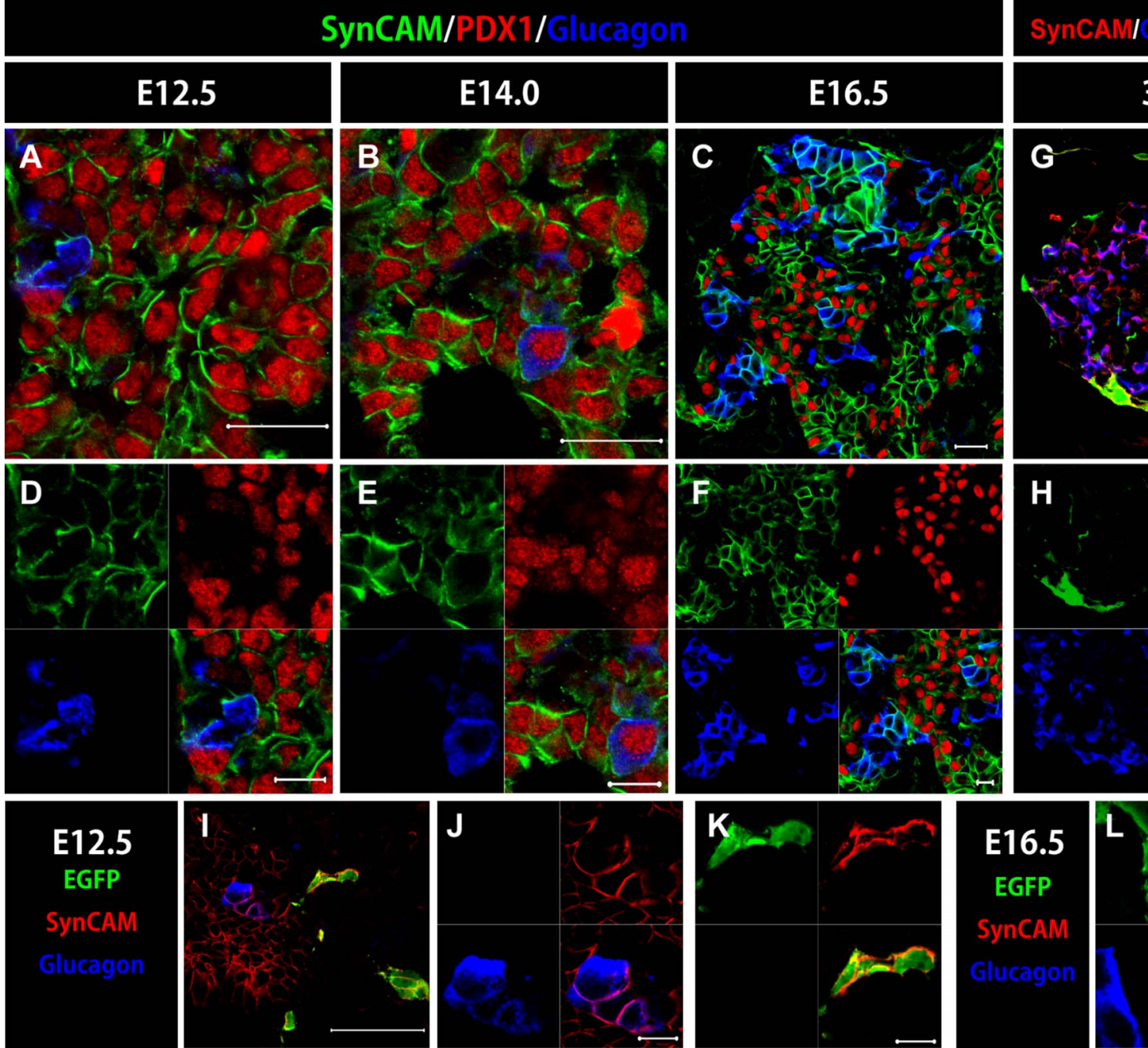

IEGFP
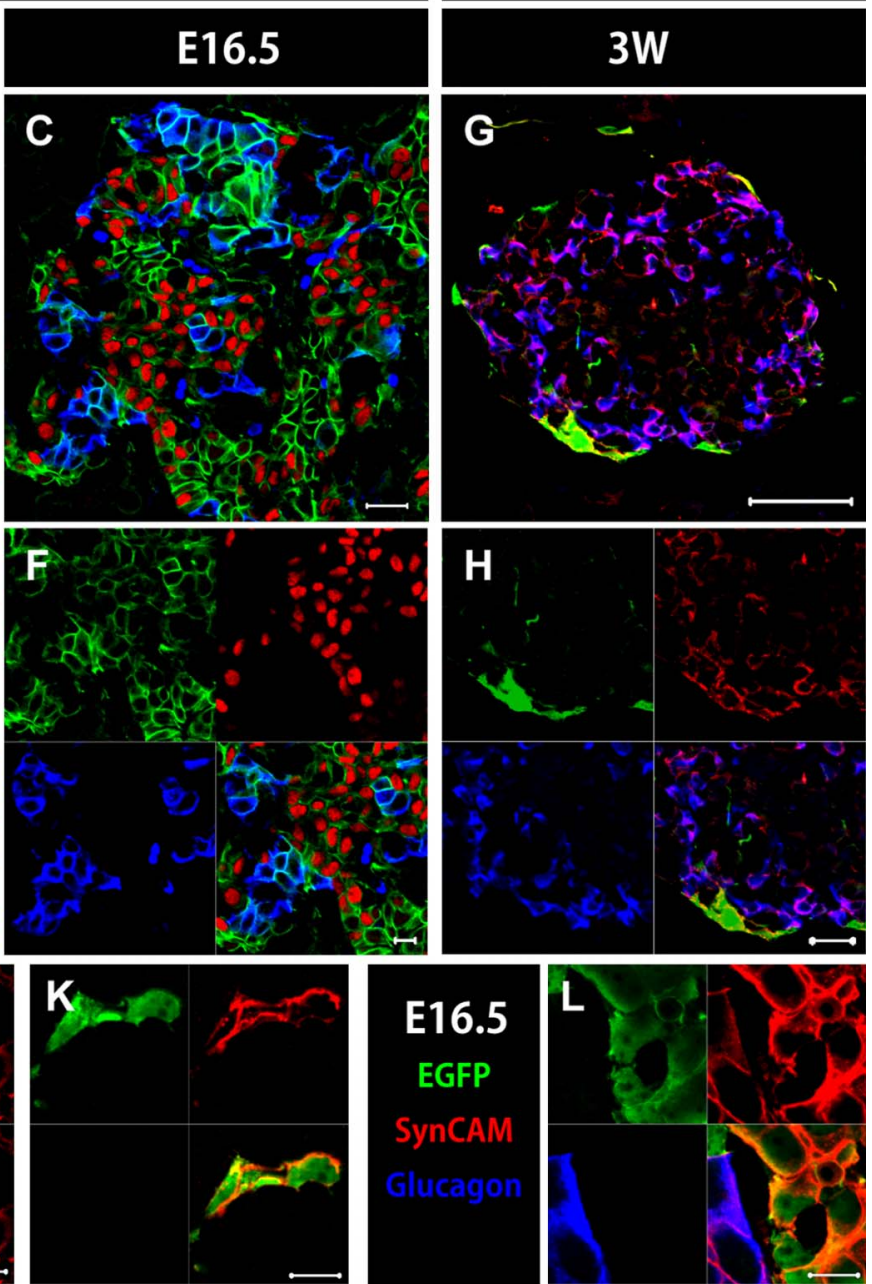

Fig. 5. SynCAM expression in the mouse pancreas. (A-F) Immunohistochemical staining of pancreatic regions of Wnt1-Cre/Floxed-EGFP mouse embryos. Staining was performed with SynCAM antibody (green), glucagon antibody (blue), and PDX1 antibody (red). (G-L) Immunohistochemical staining of embryos at E12.5, E16.5 and 3W; staining was performed with GFP antibody (green), SynCAM antibody (RED), and glucagon antibody (blue). At E12.5 and E14.0, all pancreatic epithelial cells and glucagon-positive cells were positive for SynCAM (A, B, D, and $\mathbf{E}$ ), but at E16.5, SynCAM expression was limited to the membranes of glucagon-positive cells and cells with high PDX1 expression $(\mathbf{C}$ and F). In adult pancreas, SynCAM was mainly expressed by $\mathrm{NC}$ derivatives and alpha cells $(\mathbf{G}$ and $\mathbf{H})$. At E16.5, SynCAM was expressed by membranes of NC derivatives and glucagon positive cells (L). A similar SynCAM expression pattern was confirmed at E12.5 (I, J and K). Bars $=20 \mu \mathrm{m}(\mathbf{A}-\mathbf{C}), 10 \mu \mathrm{m}(\mathbf{D}-\mathbf{F}$ and $\mathbf{J}-\mathbf{L}), 50 \mu \mathrm{m}(\mathbf{I}), 100 \mu \mathrm{m}(\mathbf{G}), 20 \mu \mathrm{m}(\mathbf{H})$. 


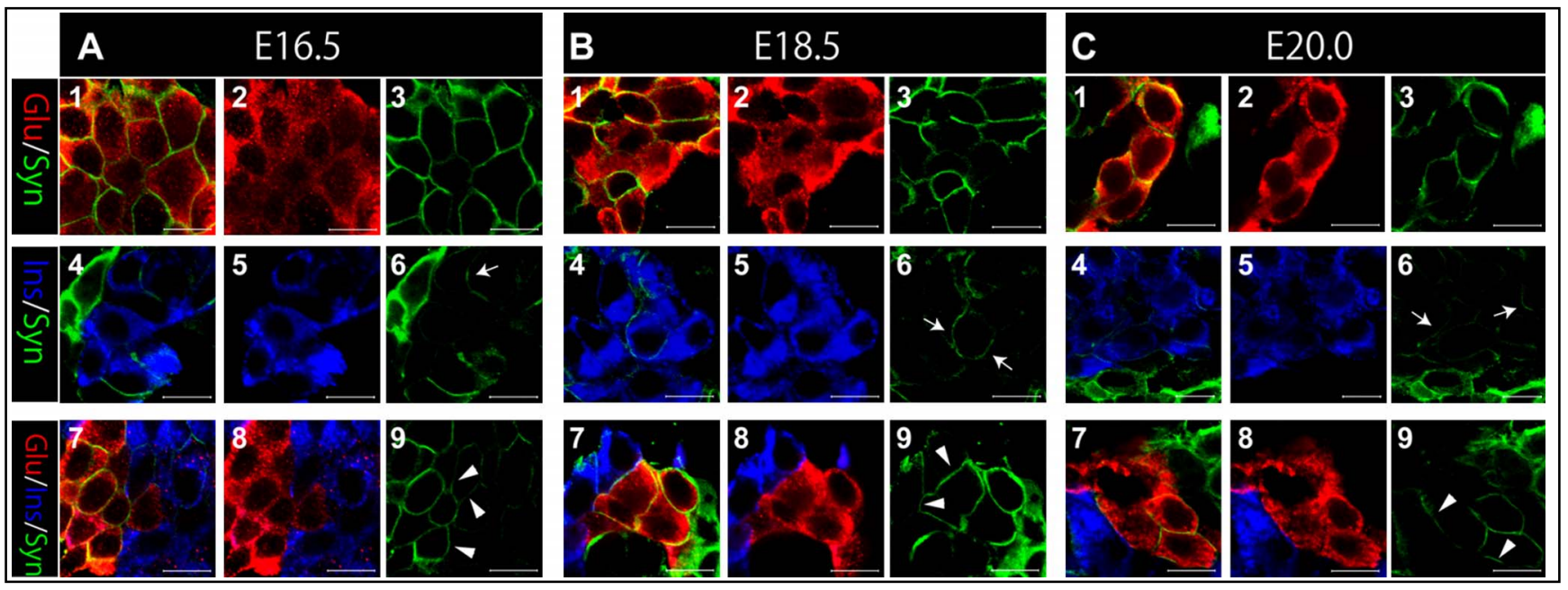

Fig. 6. SynCAM expression between each endocrine cell type during late-stage of pancreatic development. (A-C) Immunohistochemical staining of pancreatic regions of Wntl-Cre/Floxed-EGFP mouse embryos during late development stage. Staining was performed with SynCAM antibody (green), glucagon antibody (red), and insulin antibody (blue). (D-H) Immunoreactivity of SynCAM expression between alpha cells and beta cells is shown. During later stages of pancreatic development, SynCAM was expressed at the cell boundaries between alpha cells (1, 2, and 3 in $\mathbf{A}, \mathbf{B}$, and $\mathbf{C})$ and between alpha cells and beta cells (7, 8, and 9 in $\mathbf{A}$, $\mathbf{B}$, and $\mathbf{C}$ ). SynCAM expression was also confirmed between the cell boundaries of a few beta cells (4, 5, and 6 in $\mathbf{A}, \mathbf{B}$, and $\mathbf{C}$, respectively). Bar=10 $\mu \mathrm{m}$ for all Figures.

as development advanced, this tendency was remarkably increased (Fig. 4D-I). Therefore, we showed that NC derivatives tended to approach alpha cells rather than beta cells in the later stages of pancreatic development.

To confirm the gradual process whereby NC derivatives moved closer to both endocrine cell types, the characteristics of cells that appeared in a $20-\mu \mathrm{m}$ grid were examined using images obtained from the immunostaining experiments performed during stages after E14.5 (Fig. 4J). The rate at which the $\mathrm{NC}$ derivatives and endocrine cells were found to co-exist in the same grid increased as the development advanced. These results suggest that NC derivatives tended to approach the endocrine cell region rather than the exocrine cell region (Fig. 4K). Moreover, the NC derivatives enclosing the endocrine cells were distributed in closer proximity to alpha cells than to beta cells. At E16.5, approximately $60 \%$ of the NC derivatives enclosing endocrine cells were distributed in close proximity to alpha cells. This ratio increased to approximately $70 \%$ at E20. On the other hand, the rate at which NC derivatives were distributed in close proximity to beta cells was substantially decreased (Fig. 4L).

\section{During late-stage pancreatic development, both alpha cells and $\mathrm{NC}$ derivatives expressed a common cell adhesion molecule (CAM)}

Most NC derivatives were distributed in closer proximity to alpha cells than to beta cells during islet development. To investigate the cell-cell interactions between NC derivatives and alpha cells, we confirmed the expression of several CAMs. In adult mice, CADM-1, also referred to as "SynCAM", a $\mathrm{Ca}^{2+}$-independent homophilic trans-CAM, was expressed by $\mathrm{NC}$ derivatives and the membranes of alpha cells (Fig. 5G, H). During embryogenesis, we observed the temporal and spatial expression of SynCAM in the developing pancreas and confirmed that SynCAM was expressed by the cell membranes of all pancreatic epithelial cells by E14.0 (Fig. 5A, B, D, E). At E12.5, SynCAM expression was confirmed in not only the cell membranes of the pancreatic epithelial cells but also in the NC derivatives (Fig. 5I-K). As development advanced, SynCAM expression was limited to the NC derivatives, the cell membranes of endocrine cells, PDX1-positive cells, and a few exocrine cells (Fig. 5C, F, L). SynCAM expression by both NC derivatives and alpha cells was confirmed from E16.5 (Fig. 5L). Among the endocrine cells, the cell membranes of most alpha cells expressed SynCAM, but almost none of the cell membranes of beta cells did (Fig. 6A-C; arrows). SynCAM expression in the pancreas was mainly observed in the cell membranes of alpha cells and $\mathrm{NC}$ derivatives (Fig. 7A-C, G-I, M-O; arrowheads). It was also confirmed that the endocrine cells came into contact with the NC derivatives. SynCAM expression by the cell membranes of beta cells was barely detectable, and, when present, was at the cell boundaries of interacting $\mathrm{NC}$ derivatives and beta cells (Fig. 7D-F, J-L, P-R; arrowheads) or alpha cells and beta cells (Fig. 6A-C; arrowheads). SynCAM expression by the cell membranes of beta cells that were not distributed in close proximity to NC derivatives or alpha cells was either very weak or absent (Fig. 7F, L, $\mathrm{R}$; the section enclosed with dotted lines). Therefore, SynCAM expression was confirmed from E16.5 on in areas where NC derivatives came into contact with endocrine cells (Fig. 7S). These results show that during the later stages of pancreatic development, SynCAM expression is detected at the cell boundaries between NC derivatives and alpha cells as well as between NC derivatives and some beta cells. 

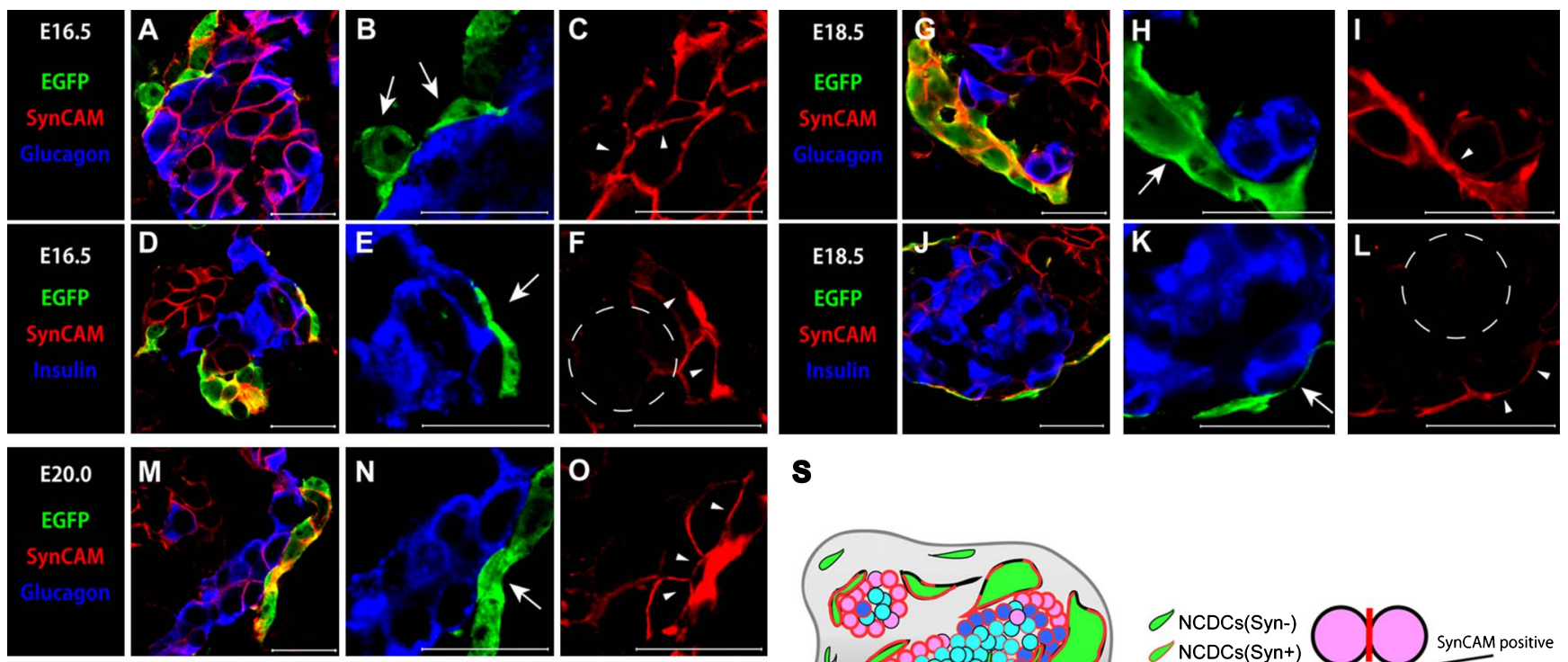

$\mathbf{S}$
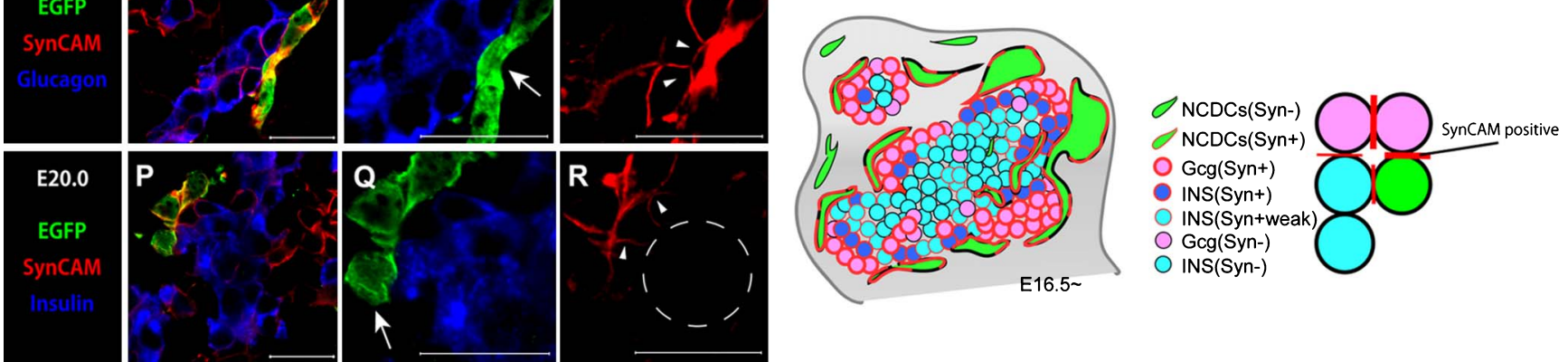

Fig. 7. SynCAM expression at the cell boundaries between NC derivatives and both endocrine cell types. (A-R) Immunohistochemical staining of pancreatic regions of Wnt1-Cre/Floxed-EGFP mouse embryos during later stages of pancreatic development. Staining was performed with SynCAM antibody (red), glucagon antibody (blue) (A, B, G, H, M, and N), insulin antibody (blue) (D, E, J, K, P, and Q), and GFP antibody. During later stages of pancreatic development, most NC derivatives came into contact with endocrine cells (B, E, $\mathbf{H}, \mathbf{K}, \mathbf{N}$, and $\mathbf{Q}$; arrows). SynCAM expression occurred at the cell boundaries between NC derivatives and endocrine cells $(\mathbf{C}, \mathbf{F}, \mathbf{I}, \mathbf{L}, \mathbf{O}$, and $\mathbf{R}$; arrowheads). The majority of endocrine cells in which SynCAM was expressed were alpha cells. Beta cells that were in contact with NC derivatives were also positive for SynCAM (F, L, R; arrowheads), but SynCAM expression was very weak or not expressed in beta cells distributed far away from NC derivatives (F, $\mathbf{L}, \mathbf{R}$; the section enclosed with dotted lines). A schematic diagram of the cellular distribution of NC derivatives and endocrine cells based on SynCAM expression pattern during later stages of pancreatic development (S). This schematic diagram shows that SynCAM was expressed during interactions among alpha cells, NC derivative cells and endocrine cells, and between alpha cells and beta cells. Bars $=20 \mu \mathrm{m}(\mathbf{A}-\mathbf{R})$.

\section{Discussion}

Previous studies have shown that signals from NC derivatives regulate the mass, proliferation, and maturation of beta cells [21, 24]. In addition, it has previously been shown that co-culturing pancreatic islets with NC stem cells in vitro promotes the regeneration of functional beta cells [22]. Therefore, it is believed that NC derivatives that migrate to the pancreatic region are important for maintenance of the function, development, and maturation of beta cells. Our results relating to the cellular distribution of $\mathrm{NC}$ derivatives at each stage of pancreatic development support NC derivative signaling of beta cells. A previous study indicated that such signals are likely to be juxtacrine signals, because neural fibers derived from NC cells are located close to insulin-positive cells at E15.5, and they contact with $98 \%$ of the insulin cell clusters by the first postnatal day [24]. However, our results show that the NC derivatives enclosing endocrine cells are located in closer proximity to alpha cells than to beta cells from the later stages of pancreatic development. Moreover, we showed that as development advances, the ratio of NC derivatives distributed in close proximity to alpha cells increases remarkably. Therefore, we suggest that the NC derivatives probably signal beta cells using juxtacrine as well as paracrine signals or a combination of both.

This tendency of NC derivatives to be distributed in close proximity to a specific cell type is of interest as it indicates that the $\mathrm{NC}$ derivatives that migrate to the pancreatic region are not distributed at random during pancreatic development. The structure of the islet cells might be related to deviations in the cellular distribution of the NC derivatives and each endocrine cell type at the embryonic stage. In rodents, the general structure of the islets is for beta cells to occupy the center and alpha cells to be distributed in the peripheral regions [23, 32]. We confirmed that in adult mice, nerve fibers and nerve-related cells tended to enclose the majority of islets. Therefore, we believe that NC derivatives and endocrine cells might have unique distributions during embryogenesis as a form of in preparation for the highly-regimented organization of the mature islets. Because NC derivatives tended to be distrib- 
uted in close proximity to endocrine cells from the fetal stage, we hypothesized that the endocrine cells and NC derivatives might use a common cellular adhesion system. Moreover, because the NC derivatives were distributed in closer proximity to alpha cells than to beta cells during islet development, we believed that a cell-cell interaction of these cell types would be important for unique cellular distributions of the endocrine cells and NC derivatives, as observed during islet development.

To investigate cell-cell interactions between the NC derivatives and alpha cells during the later stages of pancreatic development, we confirmed the expression of several CAMs. Previous studies have proven the expression of CAMs by endocrine cells $[15,28]$. We focused on CADM-1 (SynCAM), a $\mathrm{Ca}^{2+}$-independent CAM, because a previous study showed that SynCAM mediates nerve-islet cell interactions [17]. SynCAM has 3 immunoglobulin-like motifs in its extracellular domain [29, 38] and is expressed by a variety of cell types including epithelial and nonepithelial cells [1, 12-14, 38]. Previous reports have shown that SynCAM can interact with cells by homophilic binding, such as that which occurs between neurons [1] or between mast cells and neurons [8].

Our results suggest that homophilic binding of the SynCAM expressed by endocrine cells and NC derivatives contributes to endocrine cell-NC derivative interactions during islet development. Moreover, during the later stages of pancreatic development, $\mathrm{NC}$ derivatives are distributed in closer proximity to alpha cells than to beta cells, and SynCAM is also markedly expressed by NC derivatives and alpha cells at that time point. On the other hand, SynCAM expression was barely confirmed at the cell membranes of beta cells distributed near NC derivatives and alpha cells. Considering the results from previous studies as well as those from our own SynCAM expression analysis, it appears that SynCAM contributes to the aggregation of alpha cells from embryogenesis. In contrast, it is assumed that SynCAM does not contribute to the aggregation of beta cells. We propose that a mechanism regulating homophilic binding of SynCAM is responsible for the tendency of NC derivatives to be distributed in closer proximity to alpha cells than to beta cells. However, the structure of islets is also known to be mediated by several other CAMs. For example, disruption of neural CAM (NCAM) induces alpha cells to become more randomly distributed within the islets [7], and disruption of E-cadherin (ECAD) also disrupts aggregation of beta cells [3]. Although whether NCAM and ECAD disruptions mediate $\mathrm{NC}$ derivative-endocrine cell interactions remains unclear, we suggest that SynCAM is not the primary mechanism behind endocrine cell-NC derivative interactions; however, it is a mediating factor in NC derivative-endocrine cell interactions during embryogenesis.

A recent study reported that sympathetic axon terminals innervate alpha cells rather than beta cells in human islets, which have a more complex structure than rodent islets [27]. It, therefore, appears that the cellular distribution of NC derivatives that is associated with the relationship between alpha cells and nerves is not due to the distinctive structure of the rodent islets in which the beta cells occupy the center and the alpha cells are distributed at the periphery. We suggest that cell-cell interactions associated with specific SynCAM expression in the fetal pancreas are one of the factors by which the axon terminals innervate the alpha cells.

In conclusion, we elucidated the temporal and spatial cellular distribution of NC derivatives and endocrine cells during pancreatic development using Wnt1-Cre/FloxedEGFP mice. Our results strongly suggested that NC derivatives are important for islet development and for the differentiation and the maturation of endocrine cells because $\mathrm{NC}$ derivatives tended to gradually approach the endocrine cells during pancreatic development. Moreover, during the later stages of pancreatic development, the NC derivatives were distributed in closer proximity to alpha cells than to beta cells. Analysis of SynCAM expression during islet development indicated that NC derivatives might be distributed in closer proximity to alpha cells due to homophilic binding between the SynCAM expressed by the alpha cells and NC derivatives during islet development. Therefore, we suggest that SynCAM is an important factor in the relationship whereby alpha cells are distributed in the proximity of NC derivatives in adults. It is, therefore, our strong belief that interactions among NC derivatives, alpha cells, and beta cells are all essential for the induction of a physiologically competent islet, particularly from the point of view of the development and regeneration of endocrines.

\section{Acknowledgments}

We wish to thank Dr J. Miyazaki for providing the indicator mice (B6;D2-Tg(CAG-CAT-EGFP)39Miya; referred to as "CAG-CATloxP/loxP-EGFP"). We are also grateful to Dr T. Miyake and Dr T. Yoshida for their helpful discussions and comments and to T. Kimura for technical assistance. This study was supported in part by a Grant-inAid from the Ministry of Health, Labour and Welfare, Japan (H21-Nanchi-ippan-039 to T.S.), a Grant-in-Aid for Scientific Research from the Japan Society for the Promotion of Science (to K.F.), and a Novo Nordisk Pharma Insulin Award (to K.F.).

\section{References}

1. Biederer, T., Sara, Y., Mozhayeva, M., Atasoy, D., Liu, X., Kavalali, E. T. and Sudhof, T. C. (2002) SynCAM, a synaptic adhesion molecule that drives synapse assembly. Science 297; 1525-1531.

2. Burris, R. E. and Hebrok, M. (2007) Pancreatic innervation in mouse development and beta-cell regeneration. Neuroscience 150; 592-602.

3. Dahl, U., Sjodin, A. and Semb, H. (1996) Cadherins regulate aggregation of pancreatic beta-cells in vivo. Development 122; 2895-2902.

4. Danielian, P. S., Muccino, D., Rowitch, D. H., Michael, S. K. and Mcmahon, A. P. (1998) Modification of gene activity in mouse embryos in utero by a tamoxifen-inducible form of Cre recombinase. Curr. Biol. $8 ; 1323-1326$. 
5. Donev, S. R. (1984) Ultrastructural evidence for the presence of a glial sheath investing the islets of Langerhans in the pancreas of mammals. Cell Tissue Res. 237; 343-348.

6. Edvell, A. and Lindstrom, P. (1998) Vagotomy in young obese hyperglycemic mice: effects on syndrome development and islet proliferation. Am. J. Physiol. 274; E1034-1039.

7. Esni, F., Taljedal, I. B., Perl, A. K., Cremer, H., Christofori, G. and Semb, H. (1999) Neural cell adhesion molecule (N-CAM) is required for cell type segregation and normal ultrastructure in pancreatic islets. J. Cell Biol. 144; 325-337.

8. Furuno, T., Ito, A., Koma, Y., Watabe, K., Yokozaki, H., Bienenstock, J., Nakanishi, M. and Kitamura, Y. (2005) The spermatogenic Ig superfamily/synaptic cell adhesion molecule mast-cell adhesion molecule promotes interaction with nerves. J. Immunol. 174; 6934-6942.

9. Gammill, L. S. and Bronner-Fraser, M. (2003) Neural crest specification: migrating into genomics. Nat. Rev. Neurosci. 4; 795-805.

10. Gittes, G. K. (2009) Developmental biology of the pancreas: a comprehensive review. Dev. Biol. 326; 4-35.

11. Imai, J., Katagiri, H., Yamada, T., Ishigaki, Y., Suzuki, T., Kudo, H., Uno, K., Hasegawa, Y., Gao, J., Kaneko, K., Ishihara, H., Niijima, A., Nakazato, M., Asano, T., Minokoshi, Y. and Oka, Y. (2008) Regulation of pancreatic beta cell mass by neuronal signals from the liver. Science 322; 1250-1254.

12. Ito, A., Jippo, T., Wakayama, T., Morii, E., Koma, Y., Onda, H., Nojima, H., Iseki, S. and Kitamura, Y. (2003) SgIGSF: a new mast-cell adhesion molecule used for attachment to fibroblasts and transcriptionally regulated by MITF. Blood 101; 2601-2608.

13. Ito, A., Nishikawa, Y., Ohnuma, K., Ohnuma, I., Koma, Y., Sato, A., Enomoto, K., Tsujimura, T. and Yokozaki, H. (2007) SgIGSF is a novel biliary-epithelial cell adhesion molecule mediating duct/ductule development. Hepatology 45; 684-694.

14. Ito, A., Okada, M., Uchino, K., Wakayama, T., Koma, Y., Iseki, S., Tsubota, N., Okita, Y. and Kitamura, Y. (2003) Expression of the TSLC1 adhesion molecule in pulmonary epithelium and its down-regulation in pulmonary adenocarcinoma other than bronchioloalveolar carcinoma. Lab. Invest. 83; 1175-1183.

15. Jain, R. and Lammert, E. (2009) Cell-cell interactions in the endocrine pancreas. Diabetes Obes. Metab. 11 Suppl 4; 159-167.

16. Kawamoto, S., Niwa, H., Tashiro, F., Sano, S., Kondoh, G., Takeda, J., Tabayashi, K. and Miyazaki, J. (2000) A novel reporter mouse strain that expresses enhanced green fluorescent protein upon Cre-mediated recombination. FEBS Lett. 470; 263-268

17. Koma, Y., Furuno, T., Hagiyama, M., Hamaguchi, K., Nakanishi, M., Masuda, M., Hirota, S., Yokozaki, H. and Ito, A. (2008) Cell adhesion molecule 1 is a novel pancreatic-islet cell adhesion molecule that mediates nerve-islet cell interactions. Gastroenterology $134 ; 1544-1554$

18. Lausier, J., Diaz, W. C., Roskens, V., Larock, K., Herzer, K., Fong, C. G., Latour, M. G., Peshavaria, M. and Jetton, T. L. (2010) Vagal control of pancreatic beta-cell proliferation. Am. J. Physiol. Endocrinol. Metab. 299; E786-E793.

19. Le Douarin, N. M. and Kalcheim, C. (1999) The Neural Crest. Cambridge University Press, Cambridge, UK.

20. Morales, A. V., Barbas, J. A. and Nieto, M. A. (2005) How to become neural crest: from segregation to delamination. Semin. Cell Dev. Biol. 16; 655-662.

21. Nekrep, N., Wang, J., Miyatsuka, T. and German, M. S. (2008) Signals from the neural crest regulate beta-cell mass in the pancreas. Development 135; 2151-2160.

22. Olerud, J., Kanaykina, N., Vasylovska, S., King, D., Sandberg, M., Jansson, L. and Kozlova, E. N. (2009) Neural crest stem cells increase beta cell proliferation and improve islet function in co-transplanted murine pancreatic islets. Diabetologia 52; 25942601

23. Orci, L. and Unger, R. H. (1975) Functional subdivision of islets of Langerhans and possible role of D cells. Lancet 2; 1243-1244.

24. Plank, J. L., Mundell, N. A., Frist, A. Y., Legrone, A. W., Kim, T., Musser, M. A., Walter, T. J. and Labosky, P. A. (2011) Influence and timing of arrival of murine neural crest on pancreatic beta cell development and maturation. Dev. Biol. 349; 321-330.

25. Polonsky, K. S., Given, B. D. and Van Cauter, E. (1988) Twentyfour-hour profiles and pulsatile patterns of insulin secretion in normal and obese subjects. J. Clin. Invest. 81; 442-448.

26. Razavi, R., Chan, Y., Afifiyan, F. N., Liu, X. J., Wan, X., Yantha, J., Tsui, H., Tang, L., Tsai, S., Santamaria, P., Driver, J. P., Serreze, D., Salter, M. W. and Dosch, H. M. (2006) TRPV1+ sensory neurons control beta cell stress and islet inflammation in autoimmune diabetes. Cell 127; 1123-1135.

27. Rodriguez-Diaz, R., Abdulreda, M. H., Formoso, A. L., Gans, I., Ricordi, C., Berggren, P. O. and Caicedo, A. (2011) Innervation patterns of autonomic axons in the human endocrine pancreas. Cell Metab. 14; 45-54.

28. Rouiller, D. G., Cirulli, V. and Halban, P. A. (1990) Differences in aggregation properties and levels of the neural cell adhesion molecule (NCAM) between islet cell types. Exp. Cell Res. 191; 305-312.

29. Shingai, T., Ikeda, W., Kakunaga, S., Morimoto, K., Takekuni, K., Itoh, S., Satoh, K., Takeuchi, M., Imai, T., Monden, M. and Takai, Y. (2003) Implications of nectin-likemolecule-2/IGSF4/ RA175/SgIGSF/TSLC1/SynCAM1 in cell-cell adhesion and transmembrane protein localization in epithelial cells. J. Biol. Chem. 278; 35421-35427.

30. Smith, P. H. (1975) Structural modification of Schwann cells in the pancreatic islets of the dog. Am. J. Anat. 144; 513-517.

31. Smith, P. H. and Porte, D. Jr. (1976) Neuropharmacology of the pancreatic islets. Annu. Rev. Pharmacol. Toxicol. 16; 269-285.

32. Steiner, D. J., Kim, A., Miller, K. and Hara, M. (2010) Pancreatic islet plasticity: interspecies comparison of islet architecture and composition. Islets $2 ; 135-145$.

33. Steventon, B., Carmona-Fontaine, C. and Mayor, R. (2005) Genetic network during neural crest induction: from cell specification to cell survival. Semin. Cell Dev. Biol. 16; 647-654

34. Sunami, E., Kanazawa, H., Hashizume, H., Takeda, M., Hatakeyama, K. and Ushiki, T. (2001) Morphological characteristics of Schwann cells in the islets of Langerhans of the murine pancreas. Arch. Histol. Cytol. 64; 191-201.

35. Teitelman, G., Guz, Y., Ivkovic, S. and Ehrlich, M. (1998) Islet injury induces neurotrophin expression in pancreatic cells and reactive gliosis of peri-islet Schwann cells. J. Neurobiol. 34; 304318.

36. Tsui, H., Winer, S., Chan, Y., Truong, D., Tang, L., Yantha, J., Paltser, G. and Dosch, H. M. (2008) Islet glia, neurons, and beta cells. Ann. N Y Acad. Sci. 1150; 32-42.

37. Ushiki, T. and Watanabe, S. (1997) Distribution and ultrastructure of the autonomic nerves in the mouse pancreas. Microsc. Res. Tech. 37; 399-406.

38. Wakayama, T., Ohashi, K., Mizuno, K. and Iseki, S. (2001) Cloning and characterization of a novel mouse immunoglobulin superfamily gene expressed in early spermatogenic cells. Mol. Reprod. Dev. 60; 158-164.

39. Winer, S., Tsui, H., Lau, A., Song, A., Li, X., Cheung, R. K., Sampson, A., Afifiyan, F., Elford, A., Jackowski, G., Becker, D. J., Santamaria, P., Ohashi, P. and Dosch, H. M. (2003) Autoimmune islet destruction in spontaneous type 1 diabetes is not beta-cell exclusive. Nat. Med. 9; 198-205.

40. Young, H. M. and Newgreen, D. (2001) Enteric neural crestderived cells: origin, identification, migration, and differentiation. Anat. Rec. 262; 1-15

This is an open access article distributed under the Creative Commons Attribution License, which permits unrestricted use, distribution, and reproduction in any medium, provided the original work is properly cited. 